\title{
Tropical Rain Forest regeneration in an area degraded by mining in Mato Grosso State, Brazil
}

\author{
Ricardo Ribeiro Rodrigues ${ }^{\mathrm{a}}$, Sebastião Venâncio Martinss, ${ }^{\mathrm{b}, *}$ \\ Luiz Carlos de Barros ${ }^{\mathrm{c}}$

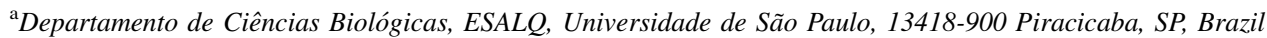 \\ ${ }^{\mathrm{b}}$ Departamento de Engenharia Florestal, Universidade Federal de Vic \undeŗosa, 36571-000 Vic \undeŗosa, MG, Brazil \\ ${ }^{\mathrm{c}}$ Programa de Pós-graduacไundeŗão em Ciências Biológicas, Instituto de Biociências, \\ Universidade Federal do Mato Grosso, 78060-900 Cuiabá, MT, Brazil
}

Received 7 May 2003; received in revised form 9 July 2003; accepted 28 October 2003

\begin{abstract}
The floristic composition and structure of vegetation in natural regeneration were studied in a degraded area in Matupá County, Mato Grosso State, Brazil, originally occupied by Tropical Rain Forest. Three plots were used in the shape of a $20 \mathrm{~m} \times 160 \mathrm{~m}$ transect, divided into $10 \mathrm{~m} \times 20 \mathrm{~m}$ sub-plots, placed parallel to a remnant fragment. Transect $1 \mathrm{was} 0-20 \mathrm{~m}$ from the fragment; Transect 2, 20-40 m, and Transect 3, 40-60 m from the forest fragment. The total height and diameter at soil height of all the shrubs and tree individuals (height $\geq 0.50 \mathrm{~m}$ ) were measured to the 5,13 and 18 months after the area had been systematized and abandoned. Floristic and structural alterations occurred in space and time. The number of individuals, species, families and diversity increased during the time interval studied and decreased with distance from the remnant fragment. These floristic and structural alterations in the community as a whole and in the populations of the most important species, Trema micrantha (L.) Blume and Schizolobium amazonicum Huber ex Ducke, showed the tendency of a succession model by facilitation, where these pioneers would be improving the ecological conditions and thus easing the regeneration of late species. The conservation of the forest fragment in the surroundings was essential for the natural regeneration process of the forest in the degraded area.
\end{abstract}

(C) 2003 Elsevier B.V. All rights reserved.

Keywords: Amazon Forest; Forest regeneration; Succession; Tropical Rain Forest

\section{Introduction}

The Amazon Forest has been suffering an accelerated degradation process through cutting to implant agricultural and electricity generation projects and disorganized mining and wood exploitations. This

\footnotetext{
* Corresponding author. Tel.: +55-31-3899-1187; fax: +55-31-3899-2478.

E-mail address: venancio@ufv.br (S.V. Martins).
}

process began in the 1960s and has been more intense in recent years, with the destruction of large areas of primary forest creating a landscape characterized by forest fragments at different succession stages, under strong pressure from man and with serious problems in preserving the biodiversity (Vieira et al., 1998; Gascon et al., 2001).

In this setting, gold mining in the north of Mato Grosso State has been an important form of environmental degradation, responsible, when considered as a 
whole, for the elimination of significant areas of the Amazon Forest. Projects are needed in the attempt to recover these degraded areas where actions such as management of natural regeneration, enrichment and tree plantation will promote the re-vegetation of these areas (Vieira et al., 1998).

In addition to legal requirements, there is currently a growing interest of mining companies in defining recovery methodologies that are suitable to the condition of the mineral extraction locality (Martins et al., 2001). Thus several models for recovery of degraded areas have been formulated, and the efficacy of each one is conditioned by factors that include degradation intensity, cost/benefit relationship of the recovery activities, local climatic and edaphic conditions and presence of remaining vegetation in the surroundings (Rodrigues and Gandolfi, 2000; Kageyama and Gandara, 2000).

The need to understand how the forest communities regenerate after human disturbances and how the species behave in the successional process of colonization of these areas is very important for degraded area recovery projects. Furthermore, it should be pointed out that the forest fragments close to the degraded areas are important sources of seeds and are therefore definers of the floristic composition and natural regeneration structure. Thus these fragments should be preserved and monitored in the planning of actions to exploit natural resources (Rodrigues and Gandolfi, 1998, 2000).

The objective of the present study was the floristic and structural characterization of the initial plant cover, promoted by natural regeneration in an area originally occupied by Tropical Rain Forest in Matupá County, Mato Grosso State, Brazil, degraded by gold mining and the analysis of the temporal and spatial alteration in this vegetation. Thus this study aimed to supply information to help in the understanding of the secondary succession in degraded areas and especially to guide the adoption of suitable restoration practices in these areas that take into account their self-recovery potential.

\section{Methods}

\subsection{Study area description}

This study was carried out in a 16 ha area, systematized after gold mining in Matupá County $\left(10^{\circ} 10^{\prime} 02^{\prime \prime} \mathrm{S}\right.$ and $\left.54^{\circ} 55^{\prime} 46^{\prime \prime} \mathrm{W}\right)$ in the state of Mato Grosso, Brazil (Fig. 1).

The climate in the region is characterized as hot and wet with a dry period in the winter and a rainy summer. The mean rainfall varies from 1800 to $2300 \mathrm{~mm}$. The soils are part of the interplateau depression of the South Amazon and are characterized as Red-Yellow Podzolic with clay texture (Mato Grosso, 1995).

The original vegetation in the study area and the remnant fragment surrounding this area is characterized as Tropical Rain Forest.

The area was subjected to gold mining activity, the forest was cut down and the superficial soil layers were removed. When the mining was finished, mechanized systematization (land leveling) of the area was carried out, and the rejected material (pebbles and sand) was used to fill in the pits dug and the remaining soil was deposited over the area.

\subsection{Vegetation analysis}

The vegetation in regeneration in the 16 ha area was sampled using three plots in the shape of $20 \mathrm{~m} \times 160 \mathrm{~m}$ transects, divided into 16 sub-plots $(10 \mathrm{~m} \times 20 \mathrm{~m})$, totaling 0.96 ha of total sampled area. The three transects were placed parallel to a forest fragment (Fig. 1). Transect 1 was 0-20 m, Transect 2, 20-40 $\mathrm{m}$ and Transect 3, 40-60 $\mathrm{m}$ from the fragment.

Three surveys of natural regeneration were made, in which the shrubs and trees with height $\geq 0.50 \mathrm{~m}$ were sampled. The first survey was conducted 5 months after the land had been systematized and the area abandoned, the second 13 months later and the third 18 months later. The total height and diameter at soil height of all the individuals were measured and botanical material was collected for identification.

The botanical material was identified by field observations, comparison with material in the herbariums at the Escola Superior de Agricultura "Luis de Queiroz"/University of São Paulo (ESA) and the Federal University of Mato Grosso (Central Herbarium) and with the help of specialists whenever necessary. Reproductive materials were incorporated in the Central Herbarium at UFMT. The scientific names were updated and standardized according to the Missouri Botanical Garden (http://mobot.mobot.org/ W3T/Search/vast.html). 


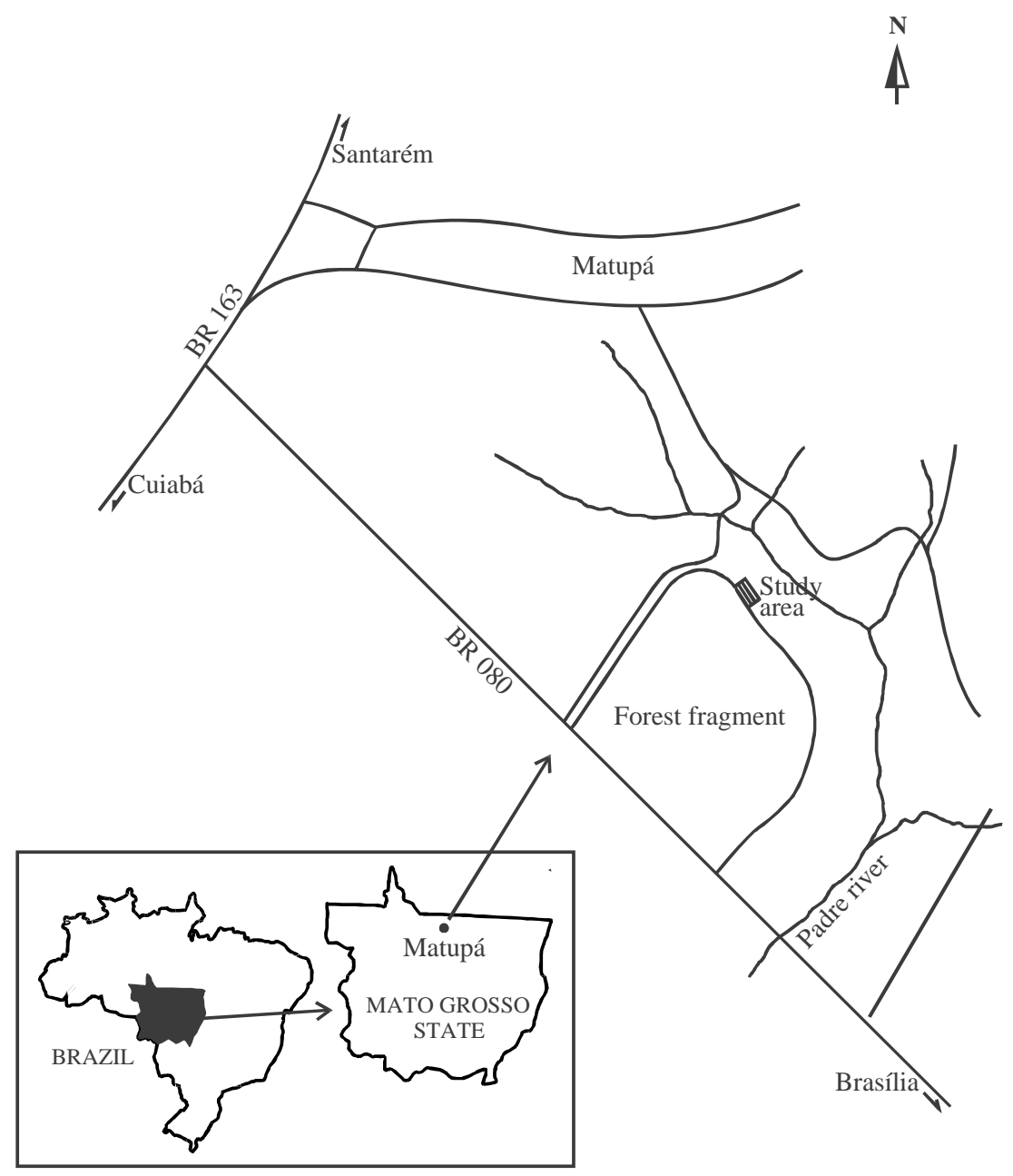

Fig. 1. Location of the study area: Matupá, Mato Grosso State, Brazil.

The phytosociological parameters were calculated according to Mueller-Dombois and Ellenberg (1974). All the analysis were performed by the FITOPAC program (Shepherd, 1995).

Importance value (IV) (Krebs, 1989) was used to analyze the relative importance of each species in each survey:

$\mathrm{IV}=\mathrm{RD}_{i}+\mathrm{RF}_{i}+\mathrm{RDo}_{i}$

where $\mathrm{RD}_{i}$ is the relative density, $\mathrm{RF}_{i}$ the relative frequency and $\mathrm{RDo}_{i}$ the relative dominance.

Diversity analysis was done with the Shannon $\left(H^{\prime}\right)$ diversity index (Magurran, 1987; Zar, 1984):
$H^{\prime}=-\sum p_{i} \ln p_{i}$

where $p_{i}$ is the proportion of the individuals in the $i$ th species.

The values of $H^{\prime}$ were compared through the $t$-test, according to Magurran (1987).

Evenness was calculated as follows (Brower and Zar, 1977):

$J^{\prime}=\frac{H^{\prime}}{H_{\max }}$

where $H^{\prime}$ is the Shannon index and $H_{\max }=\ln S$ (species richness). 


\section{Results}

Table 1 shows the sampled species in the three surveys made 5, 13 and 18 months after systematization of the degraded area (Matupá County, MT, Brazil) in the three transects.

The most frequent species in the area, sampled in the three surveys, were Trema micrantha (L.) Blume, Schizolobium amazonicum Huber ex Ducke, Cecropia purpuracens C.C.Berg., Sapium glandulatum (Vell.) Pax, Hyeronima alchorneoides Allem., Inga nobilis Willd., Myrcia sp. and Apeiba tibourbou Aubl. Another group of species was only found in the third survey, in the transect closest to the forest fragment, namely: Aspidosperma polyneuron Müll. Arg., Himatanthus obovatus (M.Arg.) Woodson, Cordia alliodora (Ruiz and Pav.) Oken, Protium robustum (Swart) D.M. Porter, Marlieria sp. and Guettarda viburnoides Cham. and Schltdl. Anacardium giganteum W. Hanc. ex Engl., Lonchocarpus sp., Quiina paraensis Pires and Fróes and Pouteria ramiflora (Mart.) Radlk. were also only found in the third survey, but more widely distributed in all three transects (Table 1).

Table 2 shows a comparison of the phytosociological data collected in the three surveys, considering the total sampled and the three transects.

There was an increase in the number of individuals, number of species and number of families and the diversity over the three surveys, both in the total area and in the three transects.

In the first survey, 5 months after systematization, considering the three transects, 2309 individuals were sampled, distributed in 25 species and 19 families.

When the first two surveys were compared for the data obtained in the total area (three transects), there was an increase of 603 individuals at 13 months after systematization of the area, passing from 2309 to 2912 plants, but the number of species and families was practically unaltered, passing from 26 and 20, respectively. Thus the diversity was also similar in the two surveys ( $t$-test, $t=0.52, P>0.1$ ).

Considering the total sampled area (three transects) the greatest floristic alterations were detected in the third survey at 18 months after systematization, when the number of individuals increased to 3307 reflecting a sharp increase in the number of species, that reached 56 and 34 families and in the diversity that, while still low, $H^{\prime}$ of 1.48 , was already superior to the value obtained at 5 months ( $t$-test, $t=10.5, P<0.001)$ and 13 months ( $t$-test, $t=14.55, P<0.001)$. In general, evenness $\left(J^{\prime}\right)$ was very low in the three surveys.

Phytosociological parameters of the 10 species presenting highest IV, considering the three transects, are presented in Table 3, in decreasing order of IV for the third survey (18 months).

T. micrantha ranked first in IV in the three surveys, followed by $S$. amazonicum. These two species were $90 \%$ of the sampled individuals at 5 months after land leveling. However, they presented different regeneration patterns during the time interval studied, with the number of $T$. micrantha individuals increasing during the three surveys while $S$. amazonicum decreased.

I. nobilis, A. tibourbou, H. alchorneoides, S. glandulatum and $C$. purpuracens were also little altered in their positions in the IV ranking in the surveys, and were always among the 10 most important species. Scheelea phalerata (Mart. ex Spreng.) Burret and Chorisia speciosa A. St.-Hil., that were ranked ninth and tenth in the IV, respectively, in the first two surveys, were not among the 10 most important species in the third survey. Some species with only one individual in the first survey were not found in the others, as in the case of Sapindus saponaria L., Triplaris americana L. and Dipteryx odorata Willd. Genipa americana L. and Ecclinusa abbreviata Ducke were represented by only one individual in the second survey that disappeared in the third survey. However, other species not sampled in the first survey, such as Citharexylum myrianthum Cham. and A. giganteum, were important in the colonization process of the area at 18 months, occupying the eighth and ninth positions, respectively, in the IV ranking.

The data in Fig. 2 shows the concentration of individuals among few families that is attributed to the high density of T. micrantha and S. amazonicum, responsible for the importance of Ulmaceae and Caesalpiniaceae, respectively. Cecropiaceae, a family represented by typically pioneer species, was not outstanding in number of individuals.

The concentration of the number of individuals in few species results in families with low species richness, that increased, however, during the study period. Thus in the first survey the family with the greatest species richness was Annonaceae, with only three species, in the second survey, Caesalpiniaceae and 
Table 1

List of species found in the Tropical Rain Forest regeneration in Matupá, MT, Brazil for the three surveys made 5, 13 and 18 months after systematization of the degraded area

\begin{tabular}{|c|c|c|c|c|}
\hline \multirow[t]{2}{*}{ Family } & \multirow[t]{2}{*}{ Species } & \multicolumn{3}{|c|}{ Transect (distance from intact forest) } \\
\hline & & $1(0-20 \mathrm{~m})$ & $2(20-40 \mathrm{~m})$ & $3(40-60 \mathrm{~m})$ \\
\hline Anacardiaceae & $\begin{array}{l}\text { A. giganteum W. Hanc. ex Engl. } \\
\text { Spondias lutea } \mathrm{L} \text {. }\end{array}$ & $\begin{array}{c}18 \\
13,18\end{array}$ & 18 & 18 \\
\hline Annonaceae & $\begin{array}{l}\text { Annona montana Macfad. } \\
\text { Guatteria poeppigiana Mart. } \\
\text { Rollinia emarginata } \text { Schltdl. } \\
\text { Xylopia emarginata Mart. }\end{array}$ & $\begin{array}{l}5,13,18 \\
5,18 \\
18 \\
5,18\end{array}$ & $\begin{array}{l}5,18 \\
5,18 \\
18 \\
5,18\end{array}$ & $\begin{array}{l}18 \\
18\end{array}$ \\
\hline Arecaceae & $\begin{array}{l}\text { Astrocaryum aculeatum G. Mey. } \\
\text { S. phalerata (Mart. ex Spreng.) Burret }\end{array}$ & $\begin{array}{l}5 \\
5,13,18\end{array}$ & $\begin{array}{l}5 \\
5,13\end{array}$ & $\begin{array}{l}13 \\
5,13,18\end{array}$ \\
\hline Apocynaceae & $\begin{array}{l}\text { A. polyneuron Müll. Arg. } \\
\text { H. obovatus (M.Arg.)Woodson }\end{array}$ & $\begin{array}{l}18 \\
18\end{array}$ & & \\
\hline Bignoniaceae & $\begin{array}{l}\text { Jacaranda copaia (Aubl.) D. Don } \\
\text { Tabebuia serratifolia (Vahl) G. Nicholson }\end{array}$ & $\begin{array}{r}13 \\
5\end{array}$ & 13 & $\begin{array}{l}13,18 \\
18\end{array}$ \\
\hline Bombacaceae & C. speciosa A. St.-Hil. & $5,13,18$ & $5,13,18$ & 5 \\
\hline Boraginaceae & C. alliodora (Ruiz and Pav.) Oken & 18 & & \\
\hline Burseraceae & $\begin{array}{l}\text { Protium heptaphyllum (Aubl.) March. } \\
\text { P. robustum (Swart) D.M. Porter }\end{array}$ & $\begin{array}{l}5,13,18 \\
18\end{array}$ & 5,13 & 5,13 \\
\hline Caesalpiniaceae & $\begin{array}{l}\text { Bauhinia longifolia D. Dietr. } \\
\text { S. amazonicum Huber ex Ducke } \\
\text { Sclerolobium guianense Benth. } \\
\text { Senna sp. }\end{array}$ & $\begin{array}{l}18 \\
5,13,18 \\
13,18\end{array}$ & $\begin{array}{l}13,18 \\
5,13,18 \\
18 \\
13,18\end{array}$ & $\begin{array}{l}18 \\
5,13,18\end{array}$ \\
\hline Caricaceae & Jacaratia spinosa (Aubl.) A. DC. & & 5,18 & \\
\hline Cecropiaceae & C. purpuracens C.C.Berg. & $5,13,18$ & $5,13,18$ & $5,13,18$ \\
\hline Clusiaceae & $\begin{array}{l}\text { Rheedia gardneriana Planch. and Triana } \\
\text { V. guianensis (Aubl.) Pers. }\end{array}$ & $\begin{array}{r}5,18 \\
13,18\end{array}$ & 18 & $\begin{array}{l}18 \\
18\end{array}$ \\
\hline Connaraceae & Connarus suberosus Planch. & & 18 & \\
\hline Chrysobalanaceae & Licania minutiflora (Sagot) Fritsch & & 18 & \\
\hline Elaeocarpaceae & Sloanea guianensis (Aubl.) Benth. & 18 & & 18 \\
\hline Euphorbiaceae & $\begin{array}{l}\text { H. alchorneoides Allem. } \\
\text { S. glandulatum (Vell.) Pax }\end{array}$ & $\begin{array}{l}5,13,18 \\
5,13,18\end{array}$ & $\begin{array}{l}5,13,18 \\
5,13,18\end{array}$ & $\begin{array}{l}5,13,18 \\
5,13,18\end{array}$ \\
\hline Fabaceae & $\begin{array}{l}\text { Andira cuyabensis Benth. } \\
\text { D. odorata Willd. } \\
\text { Lonchocarpus } \mathrm{sp} . \\
\text { Ormosia arborea (Vell.) Harms }\end{array}$ & $\begin{array}{r}5 \\
18\end{array}$ & $\begin{array}{l}18 \\
18\end{array}$ & 18 \\
\hline Flacourtiaceae & Casearia gossypiosperma Briq. & 13,18 & 13,18 & 13,18 \\
\hline Meliaceae & Cabralea canjerana (Vell.) Mart. & & 18 & \\
\hline Mimosaceae & $\begin{array}{l}\text { Anadenanthera colubrina (Vell.) Brenan } \\
\text { Hymenolobium excelsum Ducke } \\
\text { I. nobilis Willd. } \\
\text { Samanea saman (Jacq.) Merr. }\end{array}$ & $\begin{array}{l}18 \\
5,18 \\
5,13,18 \\
13,18\end{array}$ & $\begin{array}{l}18 \\
5,13 \\
5,13,18 \\
13,18\end{array}$ & $\begin{array}{l}18 \\
13 \\
5,13,18 \\
18\end{array}$ \\
\hline
\end{tabular}


Table 1 (Continued)

\begin{tabular}{|c|c|c|c|c|}
\hline \multirow[t]{2}{*}{ Family } & \multirow[t]{2}{*}{ Species } & \multicolumn{3}{|c|}{ Transect (distance from intact forest) } \\
\hline & & $1(0-20 \mathrm{~m})$ & $2(20-40 \mathrm{~m})$ & $3(40-60 \mathrm{~m})$ \\
\hline Melastomataceae & Bellucia imperialis Sald. and Cogn. & 5 & 5 & \\
\hline Moraceae & $\begin{array}{l}\text { Brossimum rubensis Taub. } \\
\text { Sorocea guilheminiana Gaudich. }\end{array}$ & $\begin{array}{l}5,18 \\
18\end{array}$ & $\begin{array}{l}18 \\
18\end{array}$ & 18 \\
\hline Myristicaceae & Virola sebifera Aubl. & 18 & & 18 \\
\hline Myrtaceae & $\begin{array}{l}\text { Marlieria sp. } \\
\text { Myrcia sp. }\end{array}$ & $\begin{array}{l}18 \\
5,13,18\end{array}$ & $5,13,18$ & $5,13,18$ \\
\hline Nyctaginaceae & Neea aff. Ovalifolia Spruce ex J.A. Schmidt & 18 & & 18 \\
\hline Ochnaceae & Ouratea castaneaefolia Engl. & & 18 & \\
\hline Proteaceae & R. obtusata Klotzsch & & & 18 \\
\hline Polygalaceae & Securidaca retusa Benth. & & 18 & \\
\hline Polygonaceae & T. americana $\mathrm{L}$. & 5 & & \\
\hline Quiinaceae & Q. paraensis Pires and Fróes & 18 & 18 & 18 \\
\hline Rhamnaceae & Colubrina glandulosa Perk. & & 18 & \\
\hline Rubiaceae & $\begin{array}{l}\text { Alibertia edulis (Rich.) A. Rich. ex DC. } \\
\text { G. americana L. } \\
\text { G. viburnoides Cham. and Schltdl. }\end{array}$ & 18 & $\begin{array}{l}18 \\
13\end{array}$ & 13 \\
\hline Sapindaceae & $\begin{array}{l}\text { Cupanea scrobiculata L.C. Rich. } \\
\text { S. saponaria } \mathrm{L} . \\
\text { Talisia } \text { sp. }\end{array}$ & $\begin{array}{c}13,18 \\
5 \\
18\end{array}$ & $\begin{array}{l}13,18 \\
18\end{array}$ & $\begin{array}{r}18 \\
5\end{array}$ \\
\hline Sapotaceae & $\begin{array}{l}\text { E. abbreviata Ducke } \\
\text { P. ramiflora (Mart.) Radlk. }\end{array}$ & $\begin{array}{l}13 \\
18\end{array}$ & $\begin{array}{l}13 \\
18\end{array}$ & 18 \\
\hline Tiliaceae & A. tibourbou Aubl. & $5,13,18$ & $5,13,18$ & $5,13,18$ \\
\hline Ulmaceae & T. micrantha (L.) Blume & $5,13,18$ & $5,13,18$ & $5,13,18$ \\
\hline Verbenaceae & C. myrianthum Cham. & 13,18 & 13,18 & 18 \\
\hline
\end{tabular}

Table 2

Phytosociological characteristics of the Tropical Rain Forest regeneration in Matupá, MT, Brazil ${ }^{\mathrm{a}}$

\begin{tabular}{|c|c|c|c|c|c|c|c|c|c|c|c|c|}
\hline & \multicolumn{3}{|c|}{ Total area } & \multicolumn{3}{|c|}{ Transect 1} & \multicolumn{3}{|c|}{ Transect 2} & \multicolumn{3}{|c|}{ Transect 3} \\
\hline & $\mathrm{f}$ & $\mathrm{s}$ & $\mathrm{t}$ & $\mathrm{f}$ & $\mathrm{s}$ & $\mathrm{t}$ & $\mathrm{f}$ & $\mathrm{s}$ & $\mathrm{t}$ & $\mathrm{f}$ & $\mathrm{s}$ & $\mathrm{t}$ \\
\hline$N$ & 2309 & 2912 & 3307 & 783 & 1124 & 1154 & 736 & 1138 & 1203 & 790 & 650 & 960 \\
\hline n. sp. & 25 & 26 & 56 & 23 & 21 & 43 & 18 & 21 & 39 & 12 & 15 & 30 \\
\hline n. fm. & 19 & 20 & 34 & 18 & 18 & 26 & 13 & 16 & 26 & 11 & 12 & 23 \\
\hline$H^{\prime}$ & 1.08 & 1.10 & 1.48 & 1.36 & 1.39 & 1.88 & 1.06 & 0.87 & 1.27 & 0.56 & 0.67 & 1.05 \\
\hline$J^{\prime}$ & 0.34 & 0.34 & 0.37 & 0.43 & 0.46 & 0.50 & 0.37 & 0.28 & 0.35 & 0.23 & 0.25 & 0.31 \\
\hline
\end{tabular}

${ }^{\text {a }} N$, number of individuals; n. sp., number of species; n. fm, number of families; $H^{\prime}$, Shannon diversity index; $J^{\prime}$, evenness; f, first survey (5 months); s, second survey (13 months); t, third survey (18 months). 
Table 3

Phytosociological parameters of the 10 species presenting highest IV of Tropical Rain Forest regeneration in Matupá, MT, Brazil ${ }^{\mathrm{a}}$

\begin{tabular}{|c|c|c|c|c|c|c|c|c|c|c|c|c|}
\hline \multirow[t]{2}{*}{ Species } & \multicolumn{3}{|l|}{$\mathrm{RD}$} & \multicolumn{3}{|l|}{ RDo } & \multicolumn{3}{|l|}{$\mathrm{RF}$} & \multicolumn{3}{|l|}{ IV } \\
\hline & $\mathrm{f}$ & s & $\mathrm{t}$ & $\mathrm{f}$ & $\mathrm{s}$ & $\mathrm{t}$ & $\mathrm{f}$ & $\mathrm{s}$ & $\mathrm{t}$ & $\mathrm{f}$ & $\mathrm{s}$ & $\mathrm{t}$ \\
\hline T. micrantha & 64.57 & 69.54 & 67.29 & 76.15 & 72.55 & 76.52 & 24.04 & 20.98 & 12.53 & 164.8 & 163.1 & 156.3 \\
\hline S. amazonicum & 25.29 & 18.92 & 12.42 & 16.64 & 18.81 & 13.84 & 14.75 & 11.61 & 7.20 & 56.68 & 49.34 & 33.46 \\
\hline I. nobilis & 2.64 & 1.75 & 2.59 & 1.79 & 1.07 & 1.53 & 10.93 & 9.38 & 7.73 & 15.36 & 12.20 & 11.85 \\
\hline A. tibourbou & 0.91 & 1.37 & 2.41 & 1.03 & 3.63 & 1.68 & 3.28 & 8.93 & 7.47 & 5.22 & 13.93 & 11.56 \\
\hline H. alchorneoides & 1.65 & 3.06 & 2.65 & 0.67 & 1.25 & 1.03 & 6.01 & 8.93 & 5.07 & 8.33 & 13.23 & 8.75 \\
\hline S. glandulatum & 0.95 & 0.96 & 1.18 & 0.59 & 0.26 & 0.31 & 7.65 & 7.59 & 5.07 & 9.19 & 8.81 & 6.55 \\
\hline C. purpuracens & 0.87 & 0.82 & 0.87 & 1.01 & 0.31 & 0.86 & 6.01 & 4.91 & 4.53 & 7.89 & 6.05 & 6.27 \\
\hline C. myrianthum & - & 0.38 & 0.90 & - & 0.19 & 0.52 & - & 2.68 & 3.47 & - & 3.25 & 4.89 \\
\hline A. giganteun & - & - & 1.21 & - & & 0.64 & - & - & 2.40 & - & - & 4.24 \\
\hline B. longifolia & - & 0.41 & 1.48 & - & 0.27 & 0.79 & - & 1.34 & 1.87 & - & 2.02 & 4.14 \\
\hline
\end{tabular}

${ }^{\mathrm{a}} \mathrm{RD}$, relative density; RDo, relative dominance; RF, relative frequency; f, first survey (5 months); s, second survey (13 months); third survey (18 months).

Mimosaceae, with three each and in the third survey, Annonaceae, Mimosaceae and Caesalpiniaceae with four species each and Fabaceae with three species.

Comparison of the phytosociological data among the three transects (Table 2) showed that the number of individuals, species and families and the diversity decreased with distance from the remnant fragment in all the surveys.

Eighteen months after the land leveling, the floristic and structural profile of natural regeneration indicated

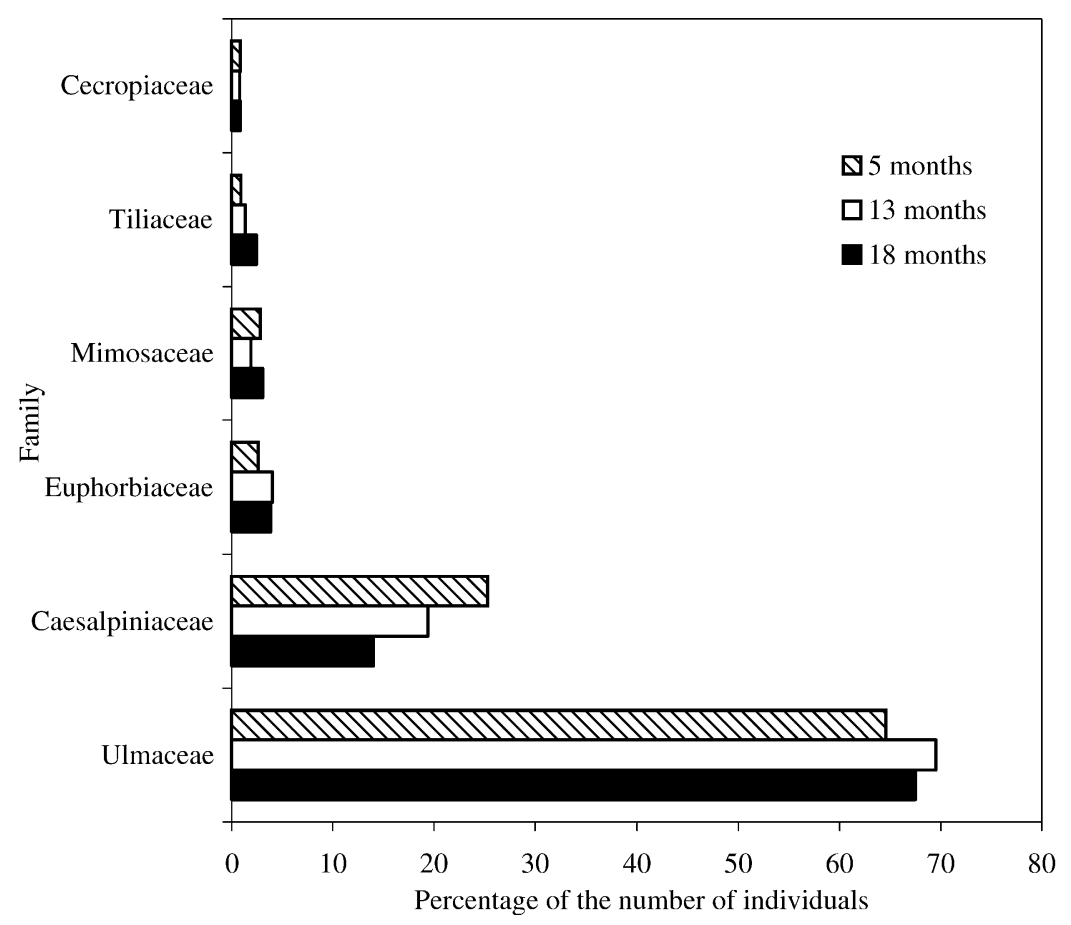

Fig. 2. Distribution (\%) of the number of individuals per family in the surveys carried out in the Tropical Rain Forest regeneration at 5,13 and 18 months, Matupá, MT, Brazil. 
Table 4

Number of individuals in the three transects (distance from intact forest), for the five species with greater IV in the third survey (18 months) of Tropical Rain Forest regeneration in Matupá, MT, Brazil

\begin{tabular}{llll}
\hline Species & $\begin{array}{l}\text { Transect 1 } \\
(0-20 \mathrm{~m})\end{array}$ & $\begin{array}{l}\text { Transect 2 } \\
(20-40 \mathrm{~m})\end{array}$ & $\begin{array}{c}\text { Transect 3 } \\
(40-60 \mathrm{~m})\end{array}$ \\
\hline T. micrantha & 605 & 873 & 754 \\
S. amazonicum & 197 & 136 & 79 \\
I. nobilis & 47 & 21 & 18 \\
A. tibourbou & 45 & 27 & 8 \\
H. alchorneoides & 62 & 13 & 13 \\
\hline
\end{tabular}

that Transect 1, the closest to the remnant fragment, presented 194 individuals, 13 species and 3 families more than Transect 3, the most distant. Thus Transect 1 presented a greater diversity than Transect 3 ( $t$-test, $t=13.55, P<0.001)$. Transect 2 presented intermediate values of all the parameters.

Table 4 shows the distribution of the number of individuals in the three transects, for the five species with greater IV in the third survey. T. micrantha was widely distributed with high density in the three transects. S. amazonicum, A. tibourbou, H. alchorneoides and I. nobilis decreased in the number of individuals with their distance from the forest fragment.

\section{Discussion}

\subsection{Temporal alterations in the floristic and structure of the natural regeneration}

The time interval analyzed permitted the characterization of the initial plant cover in the degraded area. The floristic and structural alterations that occurred among the three surveys indicated a tendency to advance in the secondary succession, the pioneer species being progressively substituted by species of later ecological groups. However, some striking differences for species were detected between the results of this study and of others carried out in the Amazon region. In several degraded and abandoned pasture areas in the Amazon Forest, initial colonization is characterized by the dominance of Vismia or Cecropia (Williamson et al., 1998; Mesquita, 2000; Ganade,
2001; Mesquita et al., 2001). Williamson et al. (1998) and Mesquita et al. (2001) reported that in these abandoned pastures, Vismia could inhibit the regeneration of late species of the primary forest, while Cecropia could ease this regeneration or not have any effect on it. In this study, Vismia guianensis (Aubl.) Pers. and C. purpuracens, the only species representative of these genera, presented low IVs. A similar pattern to the aggression of Vismia and Cecropia in other areas was exercised mainly by T. micrantha and S. amazonicum in this study. The dominance of those two species explain the low diversity and evenness in the three surveys.

In Brazil, outside the Amazon and in tropical forest in Central America, T. micrantha has been found colonizing rapidly large open areas, such as forest borders and large gaps (Brokaw, 1985, 1987; Castellani and Stubblebine, 1993; Martins and Rodrigues, 2002) and also areas with degraded soils (Denslow, 1987). In these areas, the species tends to greater growth in height and dry matter and leaf accumulation, indicating good capacity to exploit the high levels of light (Souza, 1996). High T. micrantha seed germination was obtained in alternated temperatures (Matthes, 1992; Castellani, 1996) that may also be related to the selectivity of the species for large gaps where in addition to the alteration in the spectral quality of the light, there are also large daily temperature oscillations (Vázquez-Yanes and Orozco-Segovia, 1982, 1994).

Since $T$. micrantha seeds germinate preferentially in open areas and their seedlings do not survive in natural shade conditions (Souza, 1996) and S. amazonicum, the second most important species in the area, presented a decline in density during the interval studied, it may be suggested that these species will be substituted by late species in the course of succession. Thus these more abundant pioneer species would be very important in the generation of ecological conditions, especially shade, favorable to the establishment of late secondary species originating from the adjacent forest fragment, characterizing a typical facilitation model (Connel and Slatyer, 1977). However, this is only a tendency, as the predominant succession model will be confirmed by monitoring the vegetation at longer time intervals.

This tendency of succession by a facilitation process is reinforced also by the sampling of a group of 
species not typically pioneers for the first time in the third survey, 18 months after land leveling. It is emphasized that in this group Aspidosperma polyneurom, $G$. viburnoides and $P$. robustum are late secondary species typical of mature forest at advanced succession stage (Parrotta et al., 1995; Martins and Rodrigues, 2002).

\subsection{Spatial alterations in the floristic and structure of the natural regeneration}

The spatial alterations detected in the floristic compositions and in the vegetation structure in natural regeneration showed an increase in the species richness and diversity as the sampling neared the remnant fragment.

Certain late secondary species, such as A. polyneuron and G. viburnoides, occurred only in the transect closest to the forest fragment, and among the species with greatest IV the density of $S$. amazonicum, I. nobilis, H. alchorneoides and A. tibourbou decreased with distance from the forest. S. amazonicum is a medium to large sized tree that occurs in secondary forest in the Amazon region (Parrotta et al., 1995) and although it presents anemochorous dispersal, its heavy seeds do not reach great distances. For $I$. nobilis, which is a typical zoochorous the increase in distance from the seed source must have acted as a barrier to the displacement of dispersers for the more distant transect.

These alterations in the vegetation related to the distance of the forest fragment confirm the importance of conserving these forest remnants for degraded area restoration. A negative relationship has been found between the understory colonization by native species and the intact forest distance in forest plantations on degraded tropical lands. Forest plantations placed near forest remnants tend to have faster understory colonization as well as a higher number of tree species than isolated plantations within degraded landscapes (Keenan et al., 1997; Loumeto and Huttel, 1997; Parrotta et al., 1997). Such a relationship suggests that the seeds sources proximity is one of the main limiting factors to the forest regeneration in degraded areas, once seed rain in those areas is guided by reproductive individuals density in neighboring forests, seeds production regularity, dispersal agents availability as well as the seeds dispersal distance (Hardwick et al., 1997; Wunderle, 1997).

Similarly, several studies have shown that the secondary succession process, especially in degraded and abandoned pastures, declines with the increase in distance from the forest. As most tropical tree species present anemochorous or zoochorous dispersion, the distance from the sources directly influences the quantity of seeds that arrive at the degraded area (Guevara et al., 1986; McClanahan, 1986; Gorchov et al., 1993; Barik et al., 1996; da Silva et al., 1996; Holl, 1999).

The distance from the fragment little influenced the T. micrantha distribution among the transects but the number of individuals was slightly superior in the more distant transects that may be attributed to the dispersal syndrome of the species, characterized mainly as ornitochorous. Thus its small seeds, which are very attractive to a series of birds that fly great distances, present a wider distribution pattern. A similar pattern was detected for Trema orientalis (L.) Blume in secondary forest in Thailand, where the seedling density increased with distance from the source, and viable seeds were found up to $175 \mathrm{~m}$ from the source (Cheke et al., 1979).

These floristic and structural variations among the transects may be lessened with the advance of succession, as the three sample areas offer similar shading conditions for late species and displacement and shelter for the seed dispersers.

\section{Conclusions}

In spite of the stage of degradation to which it was submitted, the studied area was in a process of forest regeneration, shown by the floristic and structural data collected.

The conservation of the forest fragment in the proximities of the area degraded by mining was essential for the natural regeneration of shrub and tree species, acting as a seed source and refuge for disperser animals.

The floristic and structural alterations during the study interval point to a gradual advance in the secondary succession, with pioneer species altering the ecological conditions and thus facilitating the regeneration of late secondary species. 


\section{References}

Barik, S.K., Tripathi, R.S., Pandey, H.N., Rao, P., 1996. Tree regeneration in a subtropical humid forest: effect of cultural disturbance on seed production, dispersal and germination. J. Appl. Ecol. 33, 1551-1560.

Brokaw, N.V.L., 1985. Gap-phase regeneration in a tropical forest. Ecology 66, 682-687.

Brokaw, N.V.L., 1987. Gap-phase regeneration of three pioneer tree species in a tropical forest. J. Ecol. 75, 9-19.

Brower, J.E., Zar, J.H., 1977. Field and laboratory methods for general ecology. Wm. C. Brown, Dubuque, IA.

Castellani, E.D., 1996. Caracterizaclundeŗão e germinaclundeŗão de sementes de Trema micrantha (L.) Blume. Tese de Mestrado. Universidade Estadual Paulista "Júlio de Mesquita Filho". Jaboticabal, São Paulo, Brazil.

Castellani, T.T., Stubblebine, W.H., 1993. Sucessão secundária inicial em mata tropical mesófila, após perturbaclunderão por fogo. Rev. Bras. Bot. 16, 181-203.

Cheke, A.S., Nanakorn, W., Yankoses, C., 1979. Dormancy and dispersal of seeds of secondary canopy of a primary tropical rain forest in Northern Thailand. Biotropica 11, 88-95.

Connel, J.H., Slatyer, R.O., 1977. Mechanisms of succession in natural communities and their role in community stability and organization. Am. Nat. 111, 1119-1144.

Denslow, J.S., 1987. Tropical rainforest gaps and tree species diversity. Ann. Rev. Ecol. Syst. 18, 431-451.

Ganade, G., 2001. Forest restoration in abandoned pastures of Central Amazonia. In: Bierregaard Jr., R.O., Gascon, C., Lovejoy, T.E., Mesquita, R.C.G. (Eds.), Lessons from Amazonia: The Ecology and Conservation of a Fragmented Forest. Yale University Press, New Haven, London, pp. 313 324.

Gascon, C., Bierregard Jr., R.O., Laurence, W., Rankin-De Mérona, J., 2001. Deforestation and forest fragmentation in the Amazon. In: Bierregard Jr., R.O., Gascon, C., Lovejoy, T.E., Mesquita, R.C.G. (Eds.), Lessons from Amazonia: The Ecology and Conservation of a Fragmented Forest. Yale University Press, New Haven, London, pp. 21-30.

Gorchov, D.L., Cornejo, F., Ascorra, C., Jaramillo, M., 1993. The role of seed dispersal in the natural regeneration of rain forest after strip-cutting in the Peruvian Amazon. Vegetatio 107, 339 349.

Guevara, S., Purata, S.E., Van der Maarel, E., 1986. The role of remnant forest trees in tropical secondary succession. Vegetatio $66,77-84$.

Hardwick, K., Healey, J., Elliott, S., Garwood, N., Anusarnsunthorn, V., 1997. Understanding and assisting natural regeneration processes in degraded seasonal evergreen forests in northern Thailand. For. Ecol. Manage. 99, 203-214.

Holl, K.D., 1999. Factors limiting tropical rain forest regeneration in abandoned pasture: seed rain, seed germination, microclimate, and soil. Biotropica 31, 229-242.

Kageyama, P.Y., Gandara, F.B., 2000. Recuperaclunderão de áreas ciliares. In: Rodrigues, R.R., Leitão Filho, H.F. (Eds.), Matas ciliares: conservaclundeŗão e recuperaclundeŗão. EDUSP, FAPESP, São Paulo, pp. 249, 269.
Keenan, R., Lamb, D., Woldring, O., Irvine, T., Jensen, R., 1997. Restoration of plant biodiversity beneath tropical tree plantations in Northern Australia. For. Ecol. Manage. 99, 117-131.

Krebs, C.J., 1989. Ecological Methodology. Harper Collins Publishers, New York.

Loumeto, J.J., Huttel, C., 1997. Understory vegetation in fastgrowing tree plantations on savanna soils in Congo. For. Ecol. Manage. 99, 65-81.

Magurran, E.A., 1987. Ecological Diversity and its Measurement. Princeton University Press, Princeton.

Martins, C.R., Leite, L.L., Haridasan, M., 2001. Recuperaclundeŗão de uma área degradada pela mineraclundeŗão de cascalho com uso de gramíneas nativas. Rev. Árvore 25, 157-166.

Martins, S.V., Rodrigues, R.R., 2002. Gap-phase regeneration in a semideciduous mesophytic forest, south-eastern Brazil. Plant Ecol. 163, 51-62.

Mato Grosso, 1995. Guia para identificaclunderão dos principais solos do Estado de Mato Grosso. PRODEAGRO/PNUD, Cuiabá.

Matthes, L.A.F., 1992. Dinâmica da sucessão secundária em mata após a ocorrência de fogo - Santa Genebra, Campinas, São Paulo. Tese de Doutorado. Universidade Estadual de Campinas, Campinas, São Paulo, Brazil.

McClanahan, T.R., 1986. The effect of a seed source on primary succession in a forest ecosystem. Vegetatio 65, 175-178.

Mesquita, R.C.G., 2000. Management of advanced regeneration in secondary forests of the Brazilian Amazon. For. Ecol. Manage. 130, 131-140.

Mesquita, R.C.G., Ickes, K., Ganade, G., Williamson, G.B., 2001. Alternative successional pathways in the Amazon Basin. J. Ecol. 89, 528-537.

Mueller-Dombois, D., Ellenberg, H., 1974. Aims and Methods of Vegetation Ecology. Wiley, New York.

Parrotta, J.A., Francis, J., Almeida, R.R., 1995. Trees of the Tapajós. United States Department of Agriculture, Forest Service, Puerto Rico.

Parrotta, J.A., Knowles, O.H., Wunderle Jr., J.M., 1997. Development of floristic diversity in 10-year-old restoration forests on bauxite mined site in Amazonia. For. Ecol. Manage. 99, 21-42.

Rodrigues, R.R., Gandolfi, S., 1998. Restauraclundeŗão de florestas tropicais: subsídios para uma definiclundeŗão metodológica e indicadores de avaliaclundeŗão e monitoramento. In: Dias, L.E., Mello, J.W.V. (Eds.), Recuperaclundeŗão de áreas degradadas. Universidade Federal de Viclunderosa, SOBRADE, Viclunderrosa, pp. 203-215.

Rodrigues, R.R., Gandolfi, S., 2000. Conceitos, tendências e aclundeŗões para a recuperaclundeŗão de florestas ciliares. In: Rodrigues, R.R., Leitão Filho, H.F. (Eds.), Matas ciliares: conservaclundeŗão e recuperaclundeŗão. EDUSP, FAPESP, São Paulo, pp. 235, 247.

Shepherd, G.J., 1995. Fitopac: manual do usuário. Departamento de Botânica, Universidade Estadual de Campinas, Campinas.

da Silva, J.M., Uhl, C., Murray, G., 1996. Plant succession, landscape management, and the ecology of frugivorous birds in abandoned Amazonian pastures. Cons. Biol. 10, 491-503.

Souza, R.P., 1996. Germinaclundeŗão, crescimento, atividade fotossintética e translocaclundeŗão de compostos de carbono em espécies arbóreas tropicais: estudo comparativo e influência 
de sombreamento natural. Tese de Doutorado. Universidade Estadual de Campinas, Campinas, São Paulo, Brazil.

Vázquez-Yanes, C., Orozco-Segovia, A., 1982. Seed germination of a tropical rain forest pioneer tree (Heliocarpus donell-smithii) in response to diurnal fluctuation of temperature. Physiol. Plant. 56, 295-298.

Vázquez-Yanes, C., Orozco-Segovia, A., 1994. Signals for seeds to sense and respond to gaps. In: Caldwell, M., Pearcy, R. (Eds.), Ecophysiological Processes Above and Below Ground. Academic Press, New York, pp. 209-236.

Vieira, G., Brandão, M.J., Blair, C., 1998. Ecofisiologia do estabelecimento de plântulas de espécies florestais da Amazô- nia. In: Higuchi, N., Campos, M.A.A., Sampaio, P.T.B., Santos, J. (Eds.), Pesquisas florestais para a conservaclunderão da floresta e reabilitaclundeŗão de áreas degradadas da Amazônia. INPA, Manaus, pp. 153-170.

Williamson, G.B., Mesquita, R.C.G., Ickes, K., 1998. Estratégias de colonizaclundeŗão de árvores pioneiras nos Neotrópicos. In: Gascon, C., Moutinho, P. (Eds.), Floresta amazônica: dinâmica, regeneraclundeŗão e manejo. INPA, Manuas, pp. 131-144.

Wunderle Jr., M.J., 1997. The role of animal seed dispersal in accelerating native forest regeneration on degraded tropical lands. For. Ecol. Manage. 99, 223-235.

Zar, J.H., 1984. Biostatistical Analysis. Prentice-Hall, London. 